\title{
Reflections on Critical Incidents of EFL Teachers During Career Entry in Central Mexico
}

\section{Reflexiones sobre incidentes críticos durante el inicio de la carrera de profesores de inglés como lengua extranjera en el centro de México*}

\section{Martha Lengeling} lengelin@ugto.mx

\section{Irasema Mora Pablo imora@ugto.mx} Universidad de Guanajuato, Guanajuato, Mexico

This article explores the reflections of critical incidents of eight beginning English as a foreign language teachers and one of their trainers in Mexico. Based upon narrative inquiry and through the use of journals, critical incidents and how they have impacted beginning teachers in their thinking were specifically looked at. From the data we found seven emerging themes which basically revolve around the relationships that are established between the teacher and the students, the emerging professional identities of the beginning teachers, and the tutor's reflection on knowledge transfer. Results showed how these teachers reflected upon their teaching practice and how the critical incidents helped them to analyze and evaluate their teaching process.

Key words: Critical incidents, foreign language, novice teachers, teacher education, teacher training.

* Received: October 4, 2015. Accepted: February 13, 2016.

How to cite this article (APA 6th ed.):

Lengeling, M. M., \& Mora Pablo, I. (2016). Reflections on critical incidents of EFL teachers during career entry in Central Mexico. HOW, 23(2), 75-88. http://dx.doi.org/10.19183/how.23.2.158.

This article is licensed under a Creative Commons Attribution-NonCommercial-NoDerivatives 4.0 International License. License Deed can be consulted at http://creativecommons.org/licenses/by-nc-nd/4.0/. 
Este artículo explora las reflexiones de ocho maestros de inglés principiantes y un instructor en México a partir de incidentes críticos. Basada en un enfoque narrativo y el uso de diarios, se investigaron los incidentes críticos y la manera en que éstos han impactado a los maestros novatos en su manera de pensar. A partir de los datos surgieron siete temas que giran en torno a las relaciones que se establecen entre maestro y estudiantes, la identidad emergente de los maestros novatos y la reflexión del tutor acerca de la transferencia del conocimiento. Los resultados mostraron cómo los maestros reflexionaron sobre su práctica docente y cómo los incidentes críticos los ayudaron a analizar y evaluar su proceso de enseñanza.

Palabras clave: educación del maestro, entrenamiento del maestro, incidentes críticos, lengua extranjera, maestros novatos.

\section{Introduction}

Teacher development refers to the opportunities that one is given to progress or to grow as professionals in English language teaching (ELT) and become as Underhill (1986) describes as "the best kind of teacher that [one] personally can be" (p. 1). As teacher trainers or educators, one of the many roles is to provide future or initial teachers with the necessary experiences and information they need to become "the best kind of teacher." This means much more than the transmission of theory, skills, and techniques, but to present novice teachers with experiences that will help them become reflective teachers for the rest of their careers. Uncovering critical incidents can be one of many ways to facilitate teachers to become more reflective and analytical. For this study, critical incidents and how they have impacted beginning teachers in their thinking are specifically looked at or examined.

In this article the term critical incidents is defined and narrative data are provided on a number of critical incidents of beginning English as a foreign language (EFL) teachers and one of their teachers in Mexico. The participants of this small scale research were all taking teacher training programs at a large public university in central Mexico and wrote about their experiences in journals. In this study our research objective was to identify and analyze beginning teachers' critical incidents and their reflections. To conclude, we will show how critical incidents can be used or explored more in teacher training programs.

\section{Literature Review}

\section{Critical Incidents}

Flanagan (1954) is known to have coined the term critical incident in his research on aviation psychology and critical incidents are found in diverse disciplines such as psychology, management, medicine, social work, communication, and education, to name a few. In ELT, they can be found in cultural studies (Stakhnevich, 2002), language learning (Finch, 2010), 
teacher education (Farrell, 2008, 2013; Johnson, 2003; Kim, Micek, \& Grigsby, 2013) and teacher training (Farrell, 2015; Richards \& Farrell, 2005). Stakhnevich (2002) provides classroom activities that use critical incidents as a way to sensitize students in understanding cross cultural misunderstandings in the English classroom. In the area of language learning, Finch (2010) states how noticing past critical incidents is helpful for learners to become aware of how these past events are influential in their learning process. Regarding teacher education, Farrell (2008) reports on a study carried out in Singapore and how the critical incidents of 18 novice teachers in a teacher education program were analyzed. This use was supportive for these beginning teachers to make sense of the complexities of the teaching practice. In another study, Farrell (2013) describes how an English teacher in Canada explored a critical incident in her classroom through the use of narrative and communication with a critical friend. Johnson (2003) provides information about how an English cooperating teacher and a student teacher in a master's program undercover critical incidents and how they can be used for professional development and narrative writing. Kim, Micek, and Grigsby's (2013) study is based upon the critical incidents as a way to explore professional dispositions of teacher candidates in relation to the evaluation of teacher training programs. Farrell (2015) and Richards and Farrell (2005) illustrate how to use critical incidents as means for teacher training.

In this article the disciplines of education and ELT are used when defining critical incidents. Measor (1985) characterizes critical incidents as the following:

Key events in the individual's life, and around which pivotal decisions revolve. These events provoke the individual into selecting particular kinds of actions, they in turn lead them in particular directions, and they end up having implications for identity...they reveal, like a flashbulb, the major choice and change times in people's lives...it becomes apparent that "critical incidents" are most likely to occur at particular times in the individual's life. These are the "periods of strain." (pp. 61-62)

These moments can have a positive or negative effect upon the individual and can activate a change or reflection. They have a lasting impact on individuals because they are memorable and forceful. They trigger decisions and changes that take place because of an action. In ELT, Farrell (2008) defines a critical incident as follows:

Any unplanned event that occurs during class ... if trainee teachers formally reflect on these critical incidents, it may be possible for them to uncover new understandings of the teaching and learning process. (p. 3)

Critical incidents are not intended, but they can provide a person with reflection which in turn results in the construction of understanding and meaning. These incidents expose aspects or learned lessons that might not have been noticed or remembered by an individual. Tripp (1993) provides information on how this term has been used historically and how it is employed in professional development as follows: 
The term "critical incident" comes from history where it refers to some event or situation which marked a significant turning-point or change in the life of a person or an institution (such as a political party) or in some social phenomenon (industrialization, a war or some legal negotiations). . .. The vast majority of critical incidents, however, are not at all dramatic or obvious: they are mostly straightforward accounts of very commonplace events that occur in routine professional practice which are critical in the rather different sense that they are indicative of underlying trends, motives, and structures. (pp. 24-25)

Again, ordinary and everyday events are found to be the source of critical incidents which create opportunities for analysis in professional practice. This evolution of a somewhat common event changes it into something more forceful and fundamental. Day (2004) states that "these [critical incidents] range from the questioning of underlying assumptions, opinions and espoused theories through the retrospective reconsideration of personal choice points, decisions, and priorities and how these may be linked to changes in patterns of professional behavior" (pp. 120-121). Both Tripp and Day point out how these events perhaps make changes in professional trajectory. Brookfield (1990) also mentions that this type of incident is a "vividly remembered event which is unplanned and unanticipated" (p. 84). So an everyday event that can often go unnoticed can be used to help a person construct meaning and understanding of this event. Richards and Farrell (2005) mention how critical incidents may "trigger insights about teaching and learning" (p. 113). Not all incidents are critical; "the point is that incidents only become critical because someone sees them as such" (Tripp, 1993, p. 27). In addition, Tripp (1993) points out that "incidents happen, but critical incidents are produced by the way we look at a situation: a critical incident is an interpretation of the significance of an event" (p. 8). So the person, who has experienced an event that he or she feels is of interest or importance, makes this event critical for her or himself. Often these events are related to something that has been learned such as a value or life lesson. In the next section, the methodology and techniques are mapped out, as well as a brief description of the participants and context.

\section{Method}

\section{Narrative Inquiry}

Narrative inquiry was a basis for this small scale research project because we were dealing with lived experiences related to teacher development. Clandinin and Connelly (2000) make mention that "narrative inquiry is a way of understanding experience. It is collaboration between researcher and participants, over time, in a place or series of places, and in social interaction with milieus" (p. 20). Two other authors, Webster and Mertova (2007), point out that: 
Narrative inquiry is human centred in that it captures and analyses life stories. In doing this, it has the ability to document critical life events in illuminating detail, and yet also reveal holistic views, qualities that give stories valuable potential for research. Stories are a reflection of the fact that experience is a matter of growth, and that understandings are continually developed, reshaped, and retold, often informally. (pp. 13-14)

Narrative inquiry has a relationship to critical incidents due to how these "life events" relate to professional growth and meaning making events. Webster and Mertova (2007) recommend the use of narratives because "narrative is well suited to addressing the complexities and subtleties of human experience in teaching and learning" (p. 1).

\section{Participants}

Data were taken from journals of eight participants; all of them were beginning their careers as EFL teachers. Some had one to two years' experience as teachers and others had just started to teach. All participants were taking training courses in ELT at a large public university in central Mexico. The eight participants were six females and two males, all of them non-native speakers.

\section{Data Collection Instrument}

For the training courses the students were asked to write in journals concerning their reflections of different aspects of teaching such as answering the following questions, among others: How did you become a teacher? What has been difficult or easy for you as a teacher? What do you like or dislike about teaching and why? What lived experiences influenced your teacher development? These questions were given at the beginning of the course as suggestions, but the students could write about other topics if they wanted to. Also during the courses, other topics were brought up in discussions as possible journal entries. The journals were for both of the researchers who were also the teacher educators. The participants wrote one journal entry per week during a semester, thus resulting in twelve entries in English. The researchers collected the journals at the middle of the semester and at the end. Feedback was given at mid-semester and this consisted of comments concerning the diary content and not the participants' use of English. The reason for doing this was to promote more reflection and writing fluency. Some of the comments might refer specifically to what a participant was writing and asking for more elaboration or providing positive feedback. From the journal entries a number of critical incidents were identified as well as reflections concerning those critical incidents.

The participants consented for us to use their journals and pseudonyms were used in order to protect the participants' identities. A journal excerpt from one of the authors is also included. 


\section{Data Analysis}

Once we detected the critical incidents from the journal entries, we read them a number of times to find emerging categories. As part of the narrative analysis, we relied on paradigmatic cognition, which, as described by Polkinghorne (1995) entails "classifying a particular instance as belonging to a category or concept" (p. 9). We looked for similarities in the data and then grouped them in a same category. Barkhuizen (2013) mentions that "thematic analyses follow the paradigmatic procedures of coding for themes, categorizing these and looking for patterns of association among them" (p. 11). With this thematic analysis we were able to identify specific categories.

Within this section, seven categories which emerged from the journal data are explored and they are: (1) Power Relations of a Beginning Teacher, (2) Teacher Realization of Students, (3) Discrimination and Wanting to Make a Difference, (4) Feeling Like a Real Teacher, (5) At the Right Time and a Friendly Mentor, (6) Student Relationships With the Teacher, and (7) Trainer's Critical Incident About Knowledge Transfer.

\section{Power Relations of a Beginning Teacher}

Novice teachers have to deal with many aspects when they begin to teach and one of them is professional relationships with other colleagues at their work contexts. A few of the teachers mentioned how they felt vulnerable as young teachers while working with more experienced teachers. In the following excerpt, a teacher, Andrea, narrates how another teacher with more experience treated her unjustly:

I've had a couple of incidents with one teacher. She just slandered me like every single day. She would make me feel so small because I did not know what I was doing. It was the principal who actually requested my coordinator to come to school and assess my performances, and when she came to the school, the books had arrived the previous week and they were on the floor. They were like a mess and I was in a panic. The teacher said: "You know, just leave the book. Go to class. Give your class." She would not let me in the homeroom. I must have knocked four to five times and she just turned and said: "Well, where is your classroom? Is it over there or here?" She had an attitude and that's when my coordinator said: "You know, you need to open the door otherwise we are going to have a problem." What was I to do? (Andrea)

Andrea had to deal with a negative attitude from another older teacher who seemed to control the younger teacher a number of times. These "periods of strain" could be seen as dominance because the older teacher, the principal, and the coordinator were involved a number of times when dealing with Andrea, who had just started her first job as an EFL teacher. This attitude did not help this teacher's career entry go smoothly and at times she had stressful events that she had to endure. These unplanned events seemed to climax until she questioned herself as a beginning teacher. A particular incident triggered critical reflection on 
the part of the participant. This questioning showed how she could reflect upon herself and perhaps even rely on some of her strengths as a young teacher. In essence, this difficult event perhaps made her stronger. This point of career entry is when beginning teachers need support from other teachers to understand what should be done and how to go about daily activities.

\section{Teacher Realization of Students}

Teachers observe their students and often will see aspects that shed light on the reality of their students. Some of the participants remarked about problems that their students had with learning English, such as students not understanding grammar, not doing their homework, or not wanting to speak in class. Besides academics, there were also teachers' personal realizations of their students and the challenges the students were facing in their personal lives. These realizations, whether academic or personal, showed a shift in the teachers' thinking. The next excerpt shows a critical incident of a teacher who makes a comment based upon her observing one of her students with the same stained shirt a number of days.

I had a kid who had stained his shirt. I think it was chamoy [a bright red fruit sauce] so it was a white shirt and red all over the shirt. Next day and the next few days he kept wearing the same shirt and I asked him: "Why do you have the same shirt? Do you have another one?" He said "No" and I asked "Why doesn't your mother clean your shirt?" and he was like "Well, I don't think she has time for me" and that just hit me that he knew his mom did not have the time. (Nadia)

Nadia noticed a small aspect of one of her students and learned something about this kid's personal life which she may never have had the opportunity to observe in a different situation. This perhaps insignificant event changes into a self-realization for the teacher concerning her student's personal life and what the reality may be for her students. This self-realization opens the teacher up to understanding and being aware of her students' context, specifically their home life.

Another teacher also reflected on how the challenges or problems that students face at home have an impact on how they perform at school. She recalls a particular student who was always active and disrupting the class:

In the group there was a boy who was always bothering and stealing things from others. He used to walk down the rows and throw down the books and notebooks from the kids' desks. He never worked in my class and I was very concerned about what to do with him, because he was the one that prompted the misbehavior of some problematic boys. (Anna)

She decided that this kid could become a "helper" in the class so she could take advantage of all his energy in a positive manner. And this seemed to work for a few weeks. But one day, she perceived a different behavior in this kid and this opened her eyes about what he was experiencing at home: 
[One day] I saw him in his chair, so quiet and he seemed to be sick. I gave him his copy and he began to work. He finished the exercise. In the next class the same happened, and the following and so on. One day I gave him another copy and he said that he did not want to color the activity. He just wrote the answers and I asked him if he felt sick. He said no, but one of the girls that was sitting in front of him said to him “¿Estás cansado ya? [Are you already tired?] and I said "¿Por qué va estar cansado?" [Why would he be tired?]. And the girl said: "Es que toma pastillas para cansarse" [Because he takes pills to get tired]. (Anna)

Then the teacher realized that the kid had been to the psychologist because of his hyperactive behavior and he was given some pills to try to control him. However, the medication was having a negative effect on him and he was not the happy and active kid he used to be. For the teacher this was critical and her comment reflected the following:

It was so sad to realize that the kid was medicated because the group teacher asked his mom to take him to the doctor. It was the only way for the boy to stay in school. Obviously, the boy changed his behavior completely, but it was not the solution for the problem. The boy indeed had a problem, but it could have been solved in a different way. Most of the time, children like this bring problems from home to school. (Anna)

This excerpt shows a complex realization for this teacher who at first did not realize her student's serious problem. Her first reaction was to solve a discipline problem by involving him more in her class and later more events took place which shed light on her student's health problem and how it was handled for him to stay in school. She has a new understanding of what her student was going through and how his family had to manage the problem.

\section{Discrimination and Wanting to Make a Difference}

Another teacher lost her job after teaching only a few months in Mexico and went to the United States to better her English. There, she worked in a restaurant and lived different experiences that made her want to return to teaching.

I quit working...actually, I got fired. I took the adventure going to the States...lived with some relatives...I tried to learn as much as I could but I got very confused... a tremendous headache. I had to listen to English all day and didn't understand a word...I decided to take some courses in ESL [English as a second language] for immigrants. I met people from different countries...I was in love with the warmth, care, and guidance that teachers gave us. I wanted to become independent, so I started being myself in the market, mall and gym...working in a restaurant to find out how the language in the workplace was. I struggled a lot...and I wanted to express my non-agreement for the unfair situation. I wanted to talk like everybody else, express my anger, and make them understand that there was abuse and racism towards me. Since then I understand when people can't communicate, how desperate and frustrated can be. I would like to help others to learn this language. (Celine) 
The incidents were both positive and negative but they seemed to influence her decision to make a difference which she describes as "help others to learn this language." From these life experiences filled with challenges she wants to make a difference by becoming an EFL teacher in Mexico. This represents a shift in her identity and is connected to what Norton (2000) mentions: "identity references desire - the desire for recognition, the desire for affiliation, and the desire for security and safety" (p. 8). Based upon Celine's past lived experiences, she is situated in the present and plans for the future which in turn creates adjustments in her identity. She wants to be a part of the teaching community as well as a role model for others.

\section{Feeling Like a Real Teacher}

The next three pieces of data represent revelations as to how the participants felt as teachers after experiencing critical incidents. During their reflections, the participants mentioned a definite change of how they saw themselves as teachers and how they felt much better about themselves as teachers. The first two excerpts were written at the end of the course.

Many things have changed since the last course. Now I'm a real English teacher. At the beginning I was very surprised because I didn't expect to be accepted... as an English teacher. (Abigail)

Well! This time I would like to talk about how I feel almost at the end of the course. I cannot believe that it is almost over. I don't want it to end! It's incredible but I enjoyed going back to school. I felt very comfortable; all of my classmates are great. I know I am going to miss them all. I'm also very happy because I'm catching up with all of the essays I had behind. Well among other things, I want to tell you how I felt about being a teacher. When you asked me that, I wasn't quite sure how to answer though...I've found out that everyone knew I was a teacher but me. (Jessica)

The above two samples could be considered somewhat confessional in that the two participants now see themselves as validated teachers: real teachers. The sum of incidents during a school year plus the training seemed to contribute to the self-realization of becoming a teacher. The criticality can be observed during the process of these participants becoming teachers. It seems to show that this process has ups and downs, but at the same time the validation they make of themselves comes from others. One may ask how they saw themselves as teachers before this realization. This may be common for beginning teachers to feel this way but one of these participants held a BA in TESOL from a state university in Mexico. The next excerpt shows how the roles of being a teacher cross over into the participant's family life:

From one day to the other, I opened my eyes to keep a sense of my position as an English teacher and a father and I am aware now that my students are different as my two sons, and they need to be approached differently by me. I am aware that my decisions can affect them positively or negatively. (Ricardo) 
Teachers might face different incidents in their daily lives as professionals. However, the way they look at these incidents allows them to make connections between their professional and their personal lives. This may seem simple but the participant makes a valuable discovery for himself as a teacher and father. This shows how the personal and professional lives coincide and how these connections can affect his relationships in two different contexts: family life and the classroom. Looking at his students beyond the image of recipients of knowledge certainly contributes to reflection upon their teaching practice.

\section{At the Right Time and a Friendly Mentor}

Another participant, Sergio, is invited by a friend to fill in for a class. The friend, an experienced native speaker teacher, tries to convince Sergio to take on the class and takes on a mentoring role. The incident is quite casual but the outcomes are more reflective in nature.

I had to live in Acapulco... working as a supervisor for a bus company...I remember that Friday very well...It was a hot day and I was the only Mexican person in the pool...a person from England named Stephen is the reason why I am an English teacher...I had to say I always liked to study English and I continued studying it for many years...Stephen asked me about my English and I answered that...my English was "dusty"...He asked: "have you taught English before?" He said that he needed a teacher for the next following Monday. I said, "Don't look at me." He tried to explain to me how easy it was...I gave him a negative answer. I had just two days to try to prepare something...I couldn't sleep that Friday, Saturday, and Sunday...My legs were shaking when I went to the classroom...I don't remember how come but after five minutes I was teaching...I looked at my watch. I couldn't believe how the time had gone by so fast...I left the classroom with my best smile. Stephen was waiting for me and he congratulated me...He said that I did it well. That day I reflected about the class and just could conclude that teaching was something I extremely enjoyed. (Sergio)

Sergio did not plan to become a teacher but an unexpected incident came about and proved to be inspirational for him. He realized that he liked being a teacher. This beginning teaching experience boosted his ego and he became conscious that teaching was something he could do and that he enjoyed it. The role of teacher who invites Sergio to take on his first class can be connected to mentoring: A more experienced individual helps someone else who has less experience with teaching (Randall \& Thornton, 2001). A mentor's roles are both "technical/assessment roles" and "personal/developmental roles" (Randall \& Thornton, 2001, p. 13). In this excerpt the roles of the mentor tended to be "personal/developmental roles" due to the confidence and motivation the mentor provided Sergio. At first Sergio felt he could not take on giving classes, but with the motivation of a more experienced teacher, Sergio found he could give a class and the experience seemed to be rewarding for him. He now had a new understanding of himself as a teacher and recognized that he likes teaching. 


\section{Student Relationships With the Teacher}

Barbara, a young teacher, begins to teach and has to deal with management problems within her classroom. Barbara started teaching in public primary schools with groups of 40-45 students and specifically had to deal with a hyperactive child and an introverted girl. At surface level the participant dealt with these problems, but more importantly she began to create solid relationships with her students and the parents.

I've had a critical incident because one of the kids was very hyper. When he got mad he'd turn things over. But I liked the incident because the kid changed. It was at the very beginning but he changed during the class. Another girl who used to be very shy, she started to get more involved with the class and at the end of the course, I saw her mom and she said "Oh, you are the teacher! Yeah, oh, my daughter, she's always saying that she doesn't like English but she knows everything." She then finished the third grade there and now where I'm working with her is at the school. She sees me and greets me and she had a good experience. (Barbara)

In the above excerpt Barbara mentions: "She sees me and greets me and she had a good experience." Barbara learned how to deal with problems and she also understood how to connect with her students, which represented a positive critical incident. Another result was that the young student enjoyed English and did not seem to reject it. For young EFL students in Mexico, this is an important step because often their experiences with English are not entirely positive and they will go through years of learning English without actually progressing in their learning (Davies, 2009; Lengeling, 2010).

\section{Trainer's Critical Incident About Knowledge Transfer}

To conclude, a journal entry of one of us teacher educators is provided to show a critical incident from a different perspective. While this is different from the beginning teachers' critical incidents, this excerpt shows how the critical incidents had an impact upon teachers and trainers. More specifically, it shows how the trainer rethought her belief of what training is and what her responsibility is concerning knowledge transfer.

I remember as a beginning COTE [Course of Overseas Teachers of English from the University of Cambridge] tutor looking at the syllabus and thinking the task of training seemed somewhat easy and straightforward. My reflection was to just teach what was on the syllabus and this knowledge would transform the teacher-learners into teachers. This thought did not last long. The more I conversed with the teacher-learners and observed them in their contexts I quickly realized that the education process was more complex that I had expected. This reflection demonstrates how I also saw myself as the giver of knowledge to the trainees. I also realized I had a hegemonic attitude toward them as learners. Why did I think I could so easily give out knowledge to others and control this process? Why did I think knowledge was such a commodity and one to give and not share or construct? Sadly, I also assumed they did not have knowledge. The realities of being a teacher trainer abruptly shook my thoughts and preconceived ideas. (Martha) 
This excerpt shows how critical incidents provide a space for individuals to reflect upon their beliefs and roles as teachers. This awareness in turn generates changes of beliefs and questioning of one's professional identity.

\section{Conclusions}

Results show that each individual reflects on critical incidents in a different way. Some of them showed how different experiences and critical incidents had an impact and helped them shape their perceptions and attitudes at a given time in their lives. Just as well, these experiences also had an impact on their identity. As presented here, some of them realized that their students were clearly experiencing problems in class but this was only a reflection of what the students were facing at home. Another mentioned how she felt discriminated against which in turned made her want to make a change in the profession. Others made comments about their students after some time of teaching and some felt recognized by their students. Teachers can analyze and examine their values, beliefs, and perceptions that underpin their actions in language teaching with these reflections.

Uncovering and recognizing critical incidents are helpful for a number of reasons. They can be used to make sense of experiences that are perhaps not clear for the person and even painful. These memorable experiences can be seen as a learning incident where valuable insights and lessons are acquired. The experiences facilitate understanding of a number of aspects such as opinions, beliefs, values, and theories, to name a few. These incidents also provoke reflection and analysis of somewhat common events but in reality they become more powerful due to what is learned.

Critical incidents are perhaps an overlooked technique for teacher training at all levels. They can be part of the repertoire of skills and techniques that one uses to help students and trainees reflect on incidents which might be easily disregarded or incidents which they have noticed as turning points. Critical incidents are memorable and even forceful in that they provide us something to reflect on and also something to be learned. Often emotions are part of these critical incidents and provide a sounding board for discussion on a number of themes such as identity, teacher development, challenges, and innovation. They also expose and represent the voices of teachers which have a relationship with narratives. Both the use of narratives and critical incidents complement each other and can be used as a teaching technique. A good example is found in James (2001) who offers advice and examples for trainers on how critical incidents can be implemented in programs.

Based on our experience, we can definitely recommend the use of critical incidents to teacher educators. An easy way to use them is by presenting what critical incidents are, followed by an elicitation of experiences that students may have had as teachers or as people. 
Later, group or whole class discussions could be carried out concerning the students' critical incidents with guided questions in order to make sense of the critical incidents. Another possibility is letting students write about their critical incidents and sharing them with another classmate or in class. Analysis of critical incidents of other students could also be carried out in class to promote reflection.

After carrying out this small scale research, we are convinced of the use of critical incidents within our teacher training as well as its being part of our own practice as teachers. These key moments provide spaces for reflection and change of challenges we encounter in our teacher development.

\section{References}

Barkhuizen, G. (Ed.). (2013). Narrative research in applied linguistics. Cambridge, UK: Cambridge University Press.

Brookfield, S. D. (1990). The skillful teacher. San Francisco, CA: Jossey Bass.

Clandinin, D. J., \& Connelly, F. M. (2000). Narrative inquiry: Experience and story in qualitative research. San Francisco, CA: Jossey-Bass.

Davies, P. (2009). Strategic management of ELT in public educational systems: Trying to reduce failure, increase success. TESL-EJ, 13(3). Retrieved from http://www.tesl-ej.org/wordpress/ issues/volume13/ej51/ej51a2/

Day, C. (2004). A passion for teaching. New York, NY: Routledge Falmer. http://dx.doi.org/ $10.4324 / 9780203464342$.

Farrell, T. S. C. (2008). Critical incidents in ELT initial teacher training. ELT Journal, 62(1), 3-10. http://dx.doi.org/10.1093/elt/ccm072.

Farrell, T. S. C. (2013). Critical incident analysis through narrative reflective practice: A case study. Iranian Journal of Language Teaching Research, 1(1), 79-89.

Farrell, T. S. C. (2015). Reflective language teaching: From research to practice. London, UK: Bloomsbury.

Finch, A. (2010). Critical incidents and language learning: Sensitivity to initial conditions. System, 38(3), 422-431. http://dx.doi.org/10.1016/j.system.2010.05.004.

Flanagan, J C. (1954). The critical incident technique. Psychological bulletin, 51(4). http://dx.doi.org/10.1037/h0061470.

James, P. (2001). Teachers in action: Tasks for in-service language teacher education and development. Cambridge, UK: Cambridge University Press.

Johnson, K. A. (2003). Every experience is a moving force: Identity and growth through mentoring. Teaching and Teacher Education, 19(8), 787-800. http://dx.doi.org/10.1016/ j.tate.2003.06.003.

Kim, S., Micek, T., \& Grigsby, Y. (2013). Investigating professionalism in ESOL teacher education through critical incident analysis and evaluation. International Journal of TESOL and Learning, 2(3), 170-186. 
Lengeling, M. M. (2010). Becoming an English teacher: Participants' voices and identities in an in-service teacher training course in central Mexico. Guanajuato, MX: Universidad de Guanajuato.

Measor, L. (1985). Critical incidents in the classroom: Identities, choices and careers. In S. J. Ball \& I. F. Goodson (Eds.), Teachers' lives and careers (pp. 61-77). London, UK: Falmer Press.

Norton, B. (2000). Identity and language learning: Gender, ethnicity and educational change. Harlow, UK: Longman.

Polkinghorne, D. E. (1995). Narrative configuration in qualitative analysis. International Journal of Qualitative Studies in Education, 8(1), 5-23. http:/ /dx.doi.org/10.1080/0951839950080103.

Randall, M., \& Thornton, B. (2001). Advising and supporting teachers. Cambridge, UK: Cambridge University Press.

Richards, J. C., \& Farrell, T. S. C. (2005). Professional development for language teachers: Strategies to teacher learning. Cambridge, UK: Cambridge University Press. http://dx.doi.org/10.1017/ CBO9780511667237.

Stakhnevich, J. (2002). Using critical incidents to teach cross-cultural sensitivity. The Internet TESL Journal, 8(3). Retrieved from http://iteslj.org/Lessons/Stakhnevich-Critical.html.

Tripp, D. (1993). Critical incidents in teaching: Developing professional judgement. New York, NY: Routledge.

Underhill, A. (1986). Editorial. Teacher Development Newsletter, 9, 4.

Webster, L., \& Mertova, P. (2007). Using narrative inquiry as a research method. London, UK: Routledge.

\section{The Authors}

M. Martha Lengeling holds a master's in TESOL (West Virginia University) and a $\mathrm{PhD}$ in Language Studies (Kent University, UK). She teaches at Universidad de Guanajuato and is a member of the National System of Researchers (Sistema Nacional de Investigadores) as well as the Editor-in-Chief of the MEXTESOL Journal.

Irasema Mora Pablo holds a PhD in Applied Linguistics (University of Kent, UK). She is the Coordinator and a teacher in the Masters in Applied Linguistics of English Language Teaching program of the Universidad de Guanajuato. She is a member of the National System of Researchers (Sistema Nacional de Investigadores). 